\title{
A Study to Compare the Cost of Operation and Maintenance in Green Building Index (GBI) and Non-Green Building Index (Non-GBI) Rated Building in Malaysia
}

\author{
Lee Zheng Ping ${ }^{1}$ and Chu Hui Chen ${ }^{2}$ \\ 1,2 Faculty of Engineering and Green Technology, University Tunku Abdul Rahman, 31900 Perak Darul Ridzuan, Malaysia
}

\begin{abstract}
Urges for sustainable development had pushed the government and professional bodies to respond and react by implementing regulations where possible to direct development in that manner. However, the outcome in most financial conferences and dialogues on sustainable buildings flagged on high construction and maintenance cost. Thus, this study is conducted to collect and analyze actual building operation and maintenance cost between GBI and Non-GBI rated buildings in Malaysia which are more than 2 years fully operated buildings. There are two categories of selected buildings which are residential and non-residential type of building. Each category of the building consists of similar building's characteristic such as geographic location, mode of operation, building heights, total numbers of floors and units. The scope of building's maintenance for this study is mainly on wear and tear of the wall painting, electrical light fittings, ceiling panels, roofing system and mechanical services like water pump system are recorded for their replacement frequency of service and the cost involved within a consistent period of 12 months operation at cost percentage saving of $78.9 \%$ and $40.4 \%$ for residential and non-residential buildings respectively compare against Non-GBI rated buildings. Electricity consumption for GBI rated buildings are lower than Non-GBI rated buildings which recorded at the cost variance of $23.8 \%$ and $6.3 \%$ and water consumption at $35.9 \%$ and $44.0 \%$ for the above mentioned two main categories of selected case study buildings. Results from this study conclude major savings on residential buildings category in term of maintenance cost and electricity consumption for GBI rated buildings. Whereby, non-residential category of buildings, GBI rated building had been proven to obtain significant savings in terms of maintenance cost and water consumption.
\end{abstract}

\section{Introduction}

Sustainable green rated buildings has become much more relevant and significant from the building's owners to the end-users. According to Fuad, it was focusing on sustainability and to be people-oriented in terms of design, usability as well as practicability [1]. By referring to Association Consulting Engineers Malaysia (ACEM) directory, the concept of green rated buildings are involves key savings drivers on "Electricity" and "Water" utilities and the 6 key elements of Energy Efficiency, Indoor Environment Quality, Sustainable Site Planning \& Management, Material and Resources, Water Efficiency and Innovation on every building that to categorized as green rated building [2] Sustainable green building study was essential to carry out in order to determine the actual cost of the building's operation and maintenance factors [3]. Indeed, the higher cost savings on building's operation and maintenance present at certain cost range in general understanding [4] but actual percentage and cost of saving was not been venture by any researchers on these 2 main type of building namely residential and non-residential of building.
The prime aim of this paper is to find out the operation and maintenance actual cost implication for a green and non-green building category. This gives us a better understanding on what is the difference of total costs to maintain green rated buildings compare to non-green rated buildings.

Throughout this study the final outcome will generates a clear understanding between similar characteristics of building but yet on different category namely on green and non-green rated building. Indirectly, it may use as a feasibility study on post-construction costing or prior after handing over of buildings to the home buyers' for cost projection on maintenance fees to be pay-off. Besides, this study will shift the understanding of the significant of the green building and create acceptable standard of awareness by disclosing the major differences on cost saving elements.

\section{Methodology}

The study adapted qualitative data collection method via criterion sampling meaning a sample that been selected to meet some criteria such as for this case study are storey of the building / building height, occupancy rate, total units, usable land area, mode of the building, years of operation and type of 
building. Instruments for collecting data can be done by observations, site survey and questionnaires or by personal construct. Consideration on size of sampling does not affect the result of the study [5]. For instance, it can be conducted 10 interviews for the same research study, but after the tenth interview might feel that no new concept emerging. For this study, 2 samples for each category of building namely residential and non-residential are collected. By using the principle of "Rules of Thumb" meaning data to collect via general principle that provides practical instructions for accomplishing or approaching a certain task [6] will be adapt on this study. Meaning only relevant to the study objectives data are collected such as actual reading on utilities and maintenance works. Each group consists of 2 samples on similar type of building that fully operated for a period more than 12 months which considered matured enough and to ensure consistency of the collected data are relatively accurate and within the same year of the study [7]. For instance, if the researcher compares a price of construction product in this year might differ from what the costing to be made for the upcoming year.

Actual domestic tariffs for electricity and water utility will collect via the respective service providers which are Tenaga Nasional Berhad (TNB) for electricity; Perbadanan Bekalan Air Pulau Pinang (PBA) and Syarikat Bekalan Air Selangor Sdn Bhd (SYABAS) for water utility in the state of Penang and Selangor respectively. As mentioned, total of 12 months consistent utility's statement to be recorded to ensure accuracy of the collected data. From the collected utilities data, total annual usages will be accumulated and multiplying with service provider rates for each of the case study building.

For building's maintenance works, the case study building will be analyze to ensure similarity of the comparison elements are obtained. For instance, maintenance works for green rated building might be different compared to non-green rated building such as flooring works for green building involves replacement of imported materials such as encaustic cement patterned flooring which might be broken, wear and tear on this product that most of the non-green rated buildings are inapplicable toward this element. Therefore, each of the comparable building's maintenance works in this study is selected based on similarity between green and non-green buildings in order to achieve comparable data analysis and discussion. Eventually all these collected visual inspection building's data and information to be analyze and illustrates via standard of basic calculation via using Microsoft Excel.

\section{Observations, Results and Discussions}

There are 2 types of building been investigated and surveyed by the researcher on this research study. There are similarity of the selected buildings in term of the type, category, location and age of the building for comparison purposes in order to compare with the similar object at different range of building category. For instance, table 3.01 below indicated 2 types of residential building, which are The Light Point Condominium and Palm Palladium Condominium whereby both located in the state of Penang. Age of all selected case study building operation are observed and maintained at minimal of 2 years fully operated. The main differences are on the construction cost as well as the annual recorded building's operation and maintenance cost. Furthermore on residential buildings, it was recorded the total construction cost between green to non-green rated buildings are at $22.6 \%$ higher. However, there is a lower building's operation and maintenance cost recorded at $78.9 \%$ saving on green rated building to non-green rated building.

Those characteristics that described above are important and to apply on non-residential buildings as tabulated below in order to achieve similarity as well as accuracy on collected data. 
Table 1: Summary of Selected Building's Observations, Results and Discussions.

\begin{tabular}{|c|c|c|c|c|}
\hline Building Category & \multicolumn{2}{|c|}{ Residential } & \multicolumn{2}{|c|}{ Non-Residential } \\
\hline Descriptions & $\begin{array}{l}\text { The Light Point } \\
\text { Condominium }\end{array}$ & $\begin{array}{l}\text { Palm Palladium } \\
\text { Condominium }\end{array}$ & $\begin{array}{l}\text { Point } 92 \text { a.k.a. } \\
\text { Menara OBYU }\end{array}$ & Menara Mudajaya \\
\hline $\begin{array}{l}\text { Illustration of } \\
\text { Actual Building's } \\
\text { Photo }\end{array}$ & & & & \\
\hline Type of Building & Condominium & Condominium & Office Commercial & Office Commercial \\
\hline $\begin{array}{l}\text { Category of } \\
\text { Building }\end{array}$ & Green Rated Building & $\begin{array}{c}\text { Non-Green Rated } \\
\text { Building } \\
\end{array}$ & Green Rated Building & $\begin{array}{c}\text { Non-Green Rated } \\
\text { Building }\end{array}$ \\
\hline $\begin{array}{l}\text { Total Built-up Area } \\
\text { (m2) }\end{array}$ & $8,091.08$ & $7,782.28$ & $3,724.46$ & $3,967.36$ \\
\hline $\begin{array}{l}\text { Building Height / } \\
\text { Floor }\end{array}$ & $\begin{array}{c}98.0 \mathrm{~m} / 28 \text {-Storey } \\
\text { Building }\end{array}$ & $\begin{array}{c}98.5 \mathrm{~m} / 28 \text {-Storey } \\
\text { Building }\end{array}$ & $\begin{array}{c}95.8 \mathrm{~m} / 19 \text {-Storey } \\
\text { Office Building }\end{array}$ & $\begin{array}{c}95.0 \mathrm{~m} / 19 \text {-Storey } \\
\text { Office Building }\end{array}$ \\
\hline Completion Date & $01^{\text {st }}$ December 2012 & $01^{\text {st }}$ July 2011 & $01^{\text {st }}$ October 2012 & $01^{\text {st }}$ September 2012 \\
\hline $\begin{array}{l}\text { Construction Cost } \\
\text { (RM) }\end{array}$ & RM68,750,000.00 & RM53,150,000.00 & RM46, $150,000.00$ & RM35,210,000.00 \\
\hline $\begin{array}{l}\text { Average Annual } \\
\text { Operation and } \\
\text { Maintenance Cost } \\
\text { (RM) }\end{array}$ & RM38, 297.70 & RM155, 032.79 & RM33, 891.92 & RM44, 395.99 \\
\hline
\end{tabular}

\section{Data Collection and Analysis}

Table 2: Summary of Building's Operation.

\begin{tabular}{|l|c|c|c|c|}
\hline Building Category & \multicolumn{2}{|c|}{ Residential } & \multicolumn{2}{c|}{ Non-Residential } \\
\hline Descriptions & $\begin{array}{c}\text { The Light Point } \\
\text { Condominium }\end{array}$ & $\begin{array}{c}\text { Palm Palladium } \\
\text { Condominium }\end{array}$ & $\begin{array}{c}\text { Point 92 a.k.a. } \\
\text { Menara OBYU }\end{array}$ & Menara Mudajaya \\
\hline Built-Up Space & $8,091.08 \mathrm{~m} 2$ & $7,782.28 \mathrm{~m} 2$ & $3,724.46 \mathrm{~m} 2$ & $3,967.36 \mathrm{~m} 2$ \\
\hline $\begin{array}{l}\text { Number of Total } \\
\text { Units }\end{array}$ & 112 & 134 & 118 & 116 \\
\hline Occupancy Rate & $90 \%$ & $90 \%$ & $95 \%$ & $95 \%$ \\
\hline $\begin{array}{l}\text { Operation Hours } \\
(06: 00-02: 00)\end{array}$ & $\begin{array}{c}24 \mathrm{Hours} \\
(06: 00-02: 00)\end{array}$ & $\begin{array}{c}18 \mathrm{Hours} \\
(06: 00-00: 00)\end{array}$ & $(06: 00-00: 00)$ \\
\hline $\begin{array}{l}\text { Usable During } \\
\text { Weekend / Public } \\
\text { Holiday }\end{array}$ & Yes & Yes & No & No \\
\hline $\begin{array}{l}\text { Electricity } \\
\text { Consumption (Kwh) }\end{array}$ & 103,638 & 125,936 & 87,125 & 93,045 \\
\hline $\begin{array}{l}\text { Water Consumption } \\
\text { (m3) }\end{array}$ & 24,860 & 38,789 & 19,461 & 34,762 \\
\hline
\end{tabular}




\subsection{Summary of Building's Operation}

Operation cost saving to compare would be the key drivers on electricity and water utilities consumption for the buildings. A total of consistent reading for 12 months utilities consumption mainly on electricity and water will analyze and recorded to compare the 2 similar functions of building but from the difference categories of building which are residential and non-residential buildings. The recorded data are collected from 1st January 2014 to 31 st December 2014, which is total of 12 months utility consumption records. For electricity, tariff to be referred to Tenaga Nasional Berhad (TNB) standard tariff based on the type and category of building via total electricity usage data. Whereby, water consumption will base on the service provider in specified state. For instance, in Selangor Darul Ehsan to referred to Syarikat Bekalan Air Selangor (SYABAS) whereby in Pulau Pinang to referred to Perbadanan Bekalan Air Pulau Pinang (PBA). For all the recording on water consumption will be recorded at the main water meter supply connection reading which is the main water inlet supply to the entire building or known as domestic bulk meter obtained from the respective service provider. Below are the summary of the total utilities consumption rate with simple calculation multiplying the service provider tariff cost for selected buildings as below:-

\subsubsection{Electricity Consumption Cost Calculation}

(a) The Light Point Condominium

The Total Annual Usage $=103,638 \mathrm{Kwh}$

TNB Calculated Tariff for Residential (Average Annual Rate) $=\mathrm{RM} 0.55 / \mathrm{Kwh}$

Total Annual Cost for Electricity Consumption = RM52, 752.00

(b) Palm Palladium Condominium

The Total Annual Usage $=125,936 \mathrm{Kwh}$

TNB Calculated Tariff for Residential (Average Annual Rate $)=\mathrm{RM} 0.55 / \mathrm{Kwh}$

Total Annual Cost for Electricity Consumption = RM69, 264.80

(c) Point 92 a.k.a. Menara OBYU

The Total Annual Usage $=87,125 \mathrm{Kwh}$

TNB Calculated Tariff for Residential (Average Annual Rate) $=\mathrm{RM} 0.42 / \mathrm{Kwh}$

Total Annual Cost for Electricity Consumption = RM36, 592.50

(d) Menara Mudajaya

The Total Annual Usage $=93,045 \mathrm{Kwh}$

TNB Calculated Tariff for Residential (Average

Annual Rate) $=$ RM0.42/Kwh

Total Annual Cost for Electricity Consumption = RM39, 078.90

From the above calculation shown that the highest differences in term of percentage for the same category of building was residential building recorded at $23.8 \%$ cost implication with annual difference between The Light Point Condominium and Palm Palladium Condominium utility cost rate at RM52, 752.00 and RM69, 264.80 respectively. Both buildings located in Island of Pulau Pinang. Besides that, non-residential building data obtained and compared between Point 92 a.k.a. Menara OBYU and Menara Mudajaya with both office commercial buildings situated at Damansara Perdana, Petaling Jaya Selangor Darul Ehsan. The recorded data showed the highest electricity usage building category which marked at RM36, 592.50 and RM39, 078.90 respectively. As described above, the highest collected data recorded on residential buildings due to the operation period operates for 24 hours daily inclusive of weekend and public holiday recorded compared to non-residential buildings which operates average of 18 hours daily excludes weekend and public holidays.

TNB electricity tariff rate shown on the calculation above is derived on average cumulative reading that collected on monthly electricity TNB's statement. For residential buildings electricity consumption for a year was recorded at $\mathrm{RM} 0.55 / \mathrm{Kwh}$ whereby non-residential buildings recorded at $\mathrm{RM} 0.42 / \mathrm{Kwh}$. There is no significant saving criteria provided by the electricity service provider of TNB. All savings elements are based on the building's total electrical usage and saving criteria that emphasized on Sustainable Green Building such as zero cost construction by utilizing building's orientation for natural lighting and ventilation caused the building's less heated by the direct sun and indirectly reduces the usage of mechanical cooling system such as air-conditioning system especially on the general areas and spaces that considered insignificant and waste of energy which highly emphasized by Point 92 a.k.a. Menara OBYU office building. Apart from that, LED lighting would be the main factors of contributing huge saving on the building's electricity usage as proven analysis that conducted by lighting specialist.

\subsubsection{Water Consumption Cost Calculation}

(a) The Light Point Condominium

The Total Annual Usage $=24,860 \mathrm{~m} 3$

PBA Calculated Tariff for Residential (Average

Annual Rate) $=$ RM0.35/m3

Total Annual Cost for Electricity Consumption = RM8, 701.00

(b) Palm Palladium Condominium

The Total Annual Usage $=38,789 \mathrm{~m} 3$

PBA Calculated Tariff for Residential (Average

Annual Rate) $=\mathrm{RM} 0.35 / \mathrm{m} 3$

Total Annual Cost for Electricity Consumption = RM13, 576.15

(c) Point 92 a.k.a. Menara OBYU

The Total Annual Usage $=19,461 \mathrm{~m} 3$

SYABAS Calculated Tariff for Residential (Average

Annual Rate) $=$ RM2.28/m3

Total Annual Cost for Electricity Consumption = RM44, 371.00

(d) Menara Mudajaya

The Total Annual Usage $=34,762 \mathrm{~m} 3$

SYABAS Calculated Tariff for Residential (Average Annual Rate $)=\mathrm{RM} 2.28 / \mathrm{m} 3$ 
Total Annual Cost for Electricity Consumption = RM79, 257.36

Referring to calculation above, water consumption with cost implication for year 2014 recorded from the selected buildings as a case study shown that both residential and non-residential buildings consumes average consumption within the range of $19,461 \mathrm{~m} 3$ to $38,789 \mathrm{~m} 3$. Specifically for residential building recorded at $24,860 \mathrm{~m} 3$ and $38,789 \mathrm{~m} 3$ for The Light Point Condominium and Palm Palladium Condominium water consumption respectively. Whereby for non-residential buildings recorded at 19,461m 3 and 34,762m3 for Point 92 a.k.a. Menara OBYU and Menara Mudajaya respectively. From the site survey, the highest saving area was evaluated and monitored at the rain water harvesting system and recyclable water system that fully utilize by the building for non-drinking purposes. Estimated more than $50 \%$ daily usage for external cleaning, landscape and building cooling system by splashing the harvesting water at the roof top to reduce the building temperature are all applied on this green rated building, which is The Light Point Condominium. Residential building recorded the lowest cost implication rate at 35.9\% differential sum between The Light Point Condominium and Palm Palladium Condominium. This due to residential buildings covered 3 main areas on each building mainly are management office, condominium general facilities such as swimming pool, washing bay, landscape and external general areas includes periodically external façade and building cleaning services. As mentioned, cost saving factor for residential building is on the recyclable water system such as rainwater harvesting system and ground water pumping system. The Light Point Condominium is located at the reclamation land and therefore obtaining from the natural source such as recyclable sea water is obtainable for legal policy usage and both residential case study buildings are applying the state water control policy which final water outlet is recorded at state water service provider bulk meter at flat rate of RM0.35 per m3 water usage. Whereby, non-residential buildings which are Point 92 a.k.a. Menara OBYU and Menara Mudajaya the rate was fixed by the Joint Member Corporation (JMC) also known as the building management board decided to fix the ceiling rate at RM2.28 per $\mathrm{m} 3$ of water usage. As a result those total costs on water consumption are slightly higher level as a comparison to residential type of buildings.

\subsection{Summary of Building's Maintenance}

Table 3: Summary of Building's Maintenance.

\begin{tabular}{|c|c|c|c|c|}
\hline \multirow{2}{*}{$\begin{array}{l}\text { Building Category / } \\
\text { Function } \\
\text { Description on Building's } \\
\text { Maintenance Works } \\
\end{array}$} & \multicolumn{2}{|c|}{ Residential } & \multicolumn{2}{|c|}{ Non-Residential } \\
\hline & $\begin{array}{l}\text { The Light Point } \\
\text { Condominium }\end{array}$ & $\begin{array}{l}\text { Palm Palladium } \\
\text { Condominium }\end{array}$ & $\begin{array}{l}\text { Point } 92 \text { a.k.a. } \\
\text { Menara OBYU }\end{array}$ & Menara Mudajaya \\
\hline $\begin{array}{l}\text { Internal and External } \\
\text { Painting Works } \\
\text { (Periodically Maintain) }\end{array}$ & $42,000.00$ & $328,422.00$ & $51,000.00$ & $57,305.00$ \\
\hline $\begin{array}{l}\text { Electrical Works } \\
\text { (Replacement on } \\
\text { Spoiled/Damaged Items } \\
\text { Only) }\end{array}$ & $7,200.00$ & $143,010.00$ & $4,704.00$ & $9,700.00$ \\
\hline $\begin{array}{l}\text { Internal Ceiling Panels } \\
\text { (Replacement on Wear \& } \\
\text { Tear Items Only) }\end{array}$ & $12,315.40$ & $3,600.00$ & $7,728.50$ & $4,680.00$ \\
\hline $\begin{array}{l}\text { Roofing Sheets } \\
\text { (Replacement on Wear \& } \\
\text { Tear Items Only) }\end{array}$ & $15,080.00$ & $51,998.39$ & $10,000.00$ & $12,780.00$ \\
\hline $\begin{array}{l}\text { Mechanical Works } \\
\text { (Study Focused On } \\
\text { Water Tank System) } \\
\end{array}$ & 0.00 & $2,665.00$ & 0.00 & $15,426.00$ \\
\hline
\end{tabular}

The collected maintenance costs involved annually tabulation on table 4.02 shown a total cost implication of RM199, 428.78 for residential and commercial building of non-green rated building (Non-GBI) whereby green rated building (GBI) recorded at RM72, 189.62; both based on total annual collected amount generated throughout the building's operation period. The cost differences in percentage between both buildings are marked at $63 \%$ of excess spending by non-green rated building. In another words, the building's owner will need to fork out additional $63 \%$ additional sum of monies if they did not adopt green building criteria with selected key elements on maintenance works stated on table
4.02. There are 3 main major maintenance works been executed by Palm Palladium Condominium that cost the highest maintenance costs spending which includes painting works at RM328, 422.00, electrical fittings and works at RM143, 010.00 and roofing sheets replacement at RM51, 998.39 in Year 2014. The main reason for painting works with huge amount spent due to local council requested the building's owner to re-paint entire building (exterior and partially interior) due to poor appearances as stipulated under state government's residential rules and regulations with the approval from Joint Member Committee (JMC) in Year 2014. All the expenditures are contributed from building's 
maintenance fees and sinking fund. Secondly, electrical fittings, JMC's with unanimous decision to make a huge change on conventional T8 fluorescent light to LED lighting for entire general areas for those categorized under strata title common areas. The pre-installation works was tested and conducted by Pascal Engineering Lighting Specialist from Penang showing huge saving on electricity by additional perk of providing 8 years maintenance free period. Next, roofing sheets replacement works to be carry out due to major leakage and rusty finishes discovered at the roof top level on roofing sheets cladding and its sub-structures, need immediate replace to avoid any calamities. Ideally, going for green rated building will generates higher positive result in longer period of time. The data above showed the building's operation range between 2 to 3 years for the case study. The lowest percentage saving on maintenance works recorded is non-residential building. It was due to low office building operation usage with slightly controlled operation hours with fixed usage period throughout the day as a result in reducing the cost of maintenance.

\section{Conclusion}

By referring to the site survey and inspection on selected case study buildings, the 6 keys elements that used on the GBI are the main consideration for this research mainly for non-green buildings are low energy efficiency by huge waste on electricity usages especially on the lighting compared to green building that encourage the usage of natural light source such as effective building's orientation and design as an innovation efforts. The main problem existed by non-green buildings are due to the pre-construction planning that lack of awareness on sustainable planning and management to make it as priority on building construction and planning requirements. As such, the indoor environment quality is more rely on mechanical system of ventilation instead of natural ventilation system. With the lack of pre-construction planning for non-green buildings, building technology are out of the development planning for instance the used of the water efficiency system such as rain water harvesting technology and solar system which widely apply on green rated buildings. Most of the non-green building's management did not practice regular maintenance that causes the entire building produce losses in operating and maintaining the building. Outcome on this study will create awareness to the building's owner and people in the industry to apply green buildings elements especially at the pre-construction planning stage. It was not merely for reputation of the company but will indirectly create long term benefits to the home buyers or tenants.

\section{References}

1. Ahmad Fuad, Building Information Modeling, Construction Research Institute of Malaysia (CREAM),

First Issue (2012)

2. Association Consulting Engineers Malaysia (ACEM) Directory. (2012). Retrieved from

http://www.acem.com.my/index.php? option $=$ com_content $\& t$ ask $=$ view\&id $=58 \&$ Itemid $=1$

3. A.M. Kassim, M.S. Jamri, M. N. Othman, M.Z.A. Rashid, S.J.S. Ismail, "Design and Development of Low Cost Certified Green Building for Non Residential Existing Building (NREB)", Advanced Materials Research, Vol. 748, 1125-1129 (2013)

4. Abu Bakar, A.H., Abd Razak, A., Abdullahi, S., Awang, A., Parumal, V., Critical Success Factor For Sustainable Housing: A Framework From The Project Management View. Asian Journal of Management Research. ISSN 2229-3795, 66-80 (2010)

5. Abdulllah, F. M., Chiet, V. C., Anuar, K., \& Shen, T. T., An Overview on the Growth and Development of the Malaysian Construction Industry. Workshop on Construction Contract Management (University Teknologi Malaysia, 2004)

6. Bell, H. R., Social Research Methods: Qualitative and Quantitative Approaches. (London: Sage Publishing Ltd, 1993).

7. Nazirah Zainul Abidin, Sustainable Construction in Malaysia - Developers' Awareness (2009). Retrieved from http://www.waset.org/journals/waset/v53/v53-131.pdf. 